\title{
Physiological Changes in the Seeds of Jatropha curcas L. at Different Stages of Fruit Maturity
}

\author{
Suheel Ahmad $^{1 *}$ and Sheikh M. Sultan ${ }^{2}$ \\ ${ }^{1}$ Indian Grassland and Fodder Research Institute; Regional Research Station; Srinagar, Jammu and Kashmir - \\ India. ${ }^{2}$ National Bureau of Plant Genetic Resources; Regional Station; Srinagar, Jammu and Kashmir - India
}

\begin{abstract}
The objective of present study was to determine appropriate fruit harvesting stage for Jatropha curcas L. for getting seeds with good oil content and better germination. The seeds separated from the fruits harvested at yellow capsule stage $\left(C_{2}\right)$ showed maximum germination efficiency, both under laboratory and nursery conditions whereas seeds separated from the fruits harvested at brownish black stage $\left(C_{3}\right)$ yielded highest oil content. Yellow capsule stage $\left(C_{2}\right)$ was physiologically mature fruit stage, which should be harvested to obtain the seeds with higher oil content besides showing maximum germination efficiency.
\end{abstract}

Key words: Jatropha curcas, Capsule maturity, Physiological changes

\section{INTRODUCTION}

Jatropha curcas L.(Family: Euphorbiaceae), commonly called as physic nut or purging nut is considered to be a promising source of non-edible oil that can be used as a feedstock for the production of biodiesel. The potential use of Jatropha oil as biodiesel feedstock has been well studied (Pramanik 2003; Reddy and Ramesh 2006; Namasivayam et al. 2007). The oil can be directly used in diesel engines after transesterification or after blending it with conventional diesel.

During the last decade Jatropha generated much interest among the researchers and policy makers for being projected as possible solution to the world's search for new energy source, and thus triggering large investments and rapid expansion of cultivation areas (GEXSI 2008). Indian Government identified it as one of the most suitable biodiesel feedstocks and actively promoted its large-scale plantation for achieving the target of $20 \%$ biofuel blending by 2017 . Being an extremely hardy drought tolerant plant and capable of growing in marginal places where most other plants fail to survive, J. curcas has been promoted as ideal plant for cultivation on nonagricultural lands, thereby not competing with the lands for food production. Under marginal conditions seed yield, however, is not satisfactory and in order to get good seed yield for oil production, the plant needs irrigation.

In general, seed yield in Jatropha is believed to be insufficient for biodiesel industry (Divakara et al. 2010). Very low female-to-male flower ratio of about 1:29-1:13, depending on the genotype is believed to be one of the most likely reasons for poor yield (Tewari et al. 2007). According to Achten et al. (2010a) Jatropha should still be considered as semi-wild and undomesticated crop and to use its full potential and to support further expansion and systematic selection, breeding and domestication are a prerequisite. Nevertheless $J$. curcas L. is a multipurpose plant providing many revenue opportunities such as oil, medicine, power generation and fertilizer. The plant has a potential

*Author for correspondence: suheel.igfri@yahoo.com 
to be integrated in diverse agro forestry systems, which in general offers better guarantee to become sustainable, and combining socio-economically viable production with environmental conservation. It prevents desertification and helps to improve the ecosystem function of marginal lands. Use of $J$. curcas biodiesel has been shown to generally reduce the global warming potential and the nonrenewable energy demand as compared to fossil biodiesel. However, the environmental impacts on acidification, ecotoxicity, eutrophication and water depletion have shown an increase (Gmunder et al. 2012). A nontoxic genotype, locally known as pinon manso (mild peanut) has been reported from Southern Mexico suitable for human consumption used in traditional Totonacon cuisine (Valdes-Rodriguez 2013).

The genus Jatropha is native to Mexico where there are 45 species, $77 \%$ of which are endemic (Rodriguez-Acosta et al. 2009). J. curcas was spread from Central America to Africa and Asia by Portuguese traders as valuable hedge plant (Fairless 2007). It has now become naturalized in many tropical and subtropical countries, including India, Indonesia, Phillippines besides, Africa and North America. The plant is well-adapted to semiarid climate, although more humid environmental conditions result in better crop performance (Tiwari et al. 2007; Achten et al. 2010b; Reubens et al. 2011). Jatropha starts bearing flowers after 90-120 days of seeding. Flowering occurs in wet season and two flowering peaks have generally been observed. In permanently humid areas, flowering occurs throughout the year. Bumper production of seeds starts after $6^{\text {th }}$ year and continues for the next 3040 years (Mundra and Rao 2003) with yields of 1.5 tons of oil per hectare (King et al. 2009). Seeds are borne in the fruit, which is trilocular, ellipsoid capsule changing color from green to yellow and finally turning blackish. Seeds (two in one cell each) are black ellipsoidal triangularconvex. Fruits mature heterogeneously because of indeterminate characteristics of the plant with fruits maturing at the bottom of the stem, while buds develop at the top. Thus, there is wide variation in the physiological maturity of the fruit ripening and senescence, thereby requiring careful manual harvesting (Silip et al. 2010). Harvesters have to select only those fruits, which are of right ripening index with seeds yielding maximum oil and mature enough to show enhanced germination upon sowing. The present study was, therefore, undertaken to identify appropriate fruit harvesting stage in J. curcas for getting seeds producing high oil yields and with enhanced germination.

\section{MATERIALS AND METHODS}

The capsules of J. curcas L. were collected from Baghaani range of Poanta Sahib Forest division, situated in Sirmour district of Himachal Pradesh ( $30^{\circ} 26^{\prime} \mathrm{N}$ latitude and $76^{\circ} 11^{\prime} \mathrm{E}$ longitude at an elevation of $320 \mathrm{~m}$ asl). The locality falls under the sub-tropical climate with May-June hottest and December-January coldest months. On an average, the annual rainfall varies from 1950-2100 $\mathrm{mm}$, most of which is experienced during the months of July-September. The annual temperature in the region ranges between $7-44^{\circ} \mathrm{C}$ with a mean value of $23.5^{\circ} \mathrm{C}$. For the collection of capsules, five trees of approximately the same age were randomly selected on the basis of their phenotypic/morphological features. These trees were tagged and marked for the collection of capsules prior to the study. The capsules were harvested at three maturity stages termed as $\mathrm{C}_{1}$ (greenish-yellow), C2 (yellow) and $\mathrm{C}_{3}$ (brownishblack) from the selected trees (Fig. 1). Capsules were picked directly from the branches throughout the height of the trees and were separately pooled at each of these stages. Seeds were separated in three sets from each pool and processed further as three replications.

Fifty seeds in each replicate selected randomly were used for the determination of moisture content and in germination test. Moisture content of the seeds was determined by drying the seeds in a hot air oven till constant weight. For germination, the seeds were placed in germination trays lined with wet filter paper and incubated in a germination chamber at $30^{\circ} \mathrm{C}$ for 15 days. The seeds were counted as germinated when radical emergence took place under laboratory conditions and when cotyledons emerged from the soil in nursery studies.

For the estimation of various tissue constituents, one gram dried coarse powdered seed sample in triplicate was placed in a beaker containing 20 to $25 \mathrm{~mL}$ of boiling $80 \%$ ethanol for $10 \mathrm{~min}$ and filtered. The residue was again extracted in 10 to $15 \mathrm{~mL}$ of boiling $80 \%$ ethanol for three to five min and filtered. The supernatants were combined and the final volume was made to $50 \mathrm{~mL}$ and used 
for estimation of total sugars, reducing sugars, non-reducing sugars and total phenols; the residue was used for the estimation of starch.

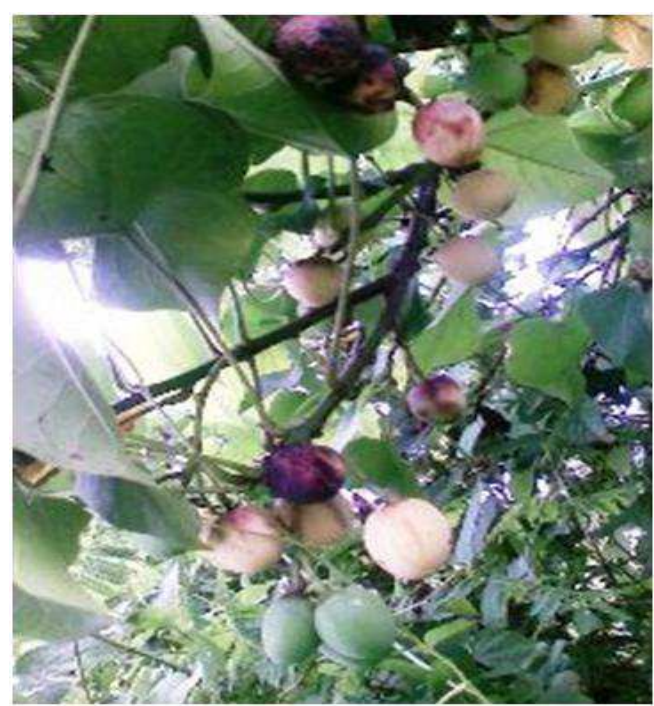

Figure 1 - Fruits at different stages of maturity in Jatropha curcas.

Total soluble sugars were estimated by the phenol-sulphuric acid method using glucose as standard (Dubois et al. 1956). Reducing sugars were estimated by 3,5-dinitrosalicylic acid (DNS) method using glucose as standard (Miller 1959) and non-reducing sugars were expressed as difference between total sugars and reducing sugars. Total phenols were estimated by the method of Bray and Thorpe (1954) using gallic acid as standard. The residue was hydrolyzed by adding 5.0 mLof distilled water and $6.0 \mathrm{~mL}$ of $52 \%$ perchloric acid. The contents were stirred for $30 \mathrm{~min}$, followed by the addition of $20 \mathrm{~mL}$ of distilled water. After filteration, the volume was made to $100 \mathrm{ml}$ and glucose was determined by phenol-sulphuric acid method of Dubois et al. (1956). Starch content was calculated by multiplying this value with the conversion factor of 0.9 and expressed as $\mathrm{mg} / \mathrm{g}$ of dry weight.

For the estimation of oil content, seed kernels were crushed using pestle and mortar and the oil from a known weight of this powdered sample was extracted in petroleum ether $\left(60-80^{\circ} \mathrm{C}\right)$ in Soxhlet apparatus placed over a heating mantle for $6 \mathrm{~h}$. The ether was completely evaporated on a water bath and the percentage oil yield was calculated as follows:

$$
\text { Oil content }(\%)=\frac{\text { Oil weight }}{\text { Sample weight }} \times 100
$$

The correlation coefficient was worked out for data at $\mathrm{C}_{2}$ stage of capsule maturity by using the formula of Panse and Sukhatme (1978).

\section{RESULTS AND DISCUSSION}

Jatropha curcas exhibiting non-synchronous flowering and fruiting bears capsules almost round the year, which mature non-synchronously. Fruits are initially green, changing colour first to greenish-yellow, then yellowish and finally to brownish-black. Due to this non-uniform fruit ripening, all the stages of capsule maturity are observed on the same plant or even on the same branch (Fig. 1). When the seeds from three stages of capsule maturity designated as $\mathrm{C}_{1}$ (greenishyellow), $\mathrm{C}_{2}$ (yellowish) and $\mathrm{C}_{3}$ (brownish-black) were examined for germination efficiency, lowest germination was recorded in the seeds collected at stage $\mathrm{C}_{1}$ and highest in the seeds collected at stage $\mathrm{C}_{2}$ of capsule maturity (Table 1 ).

Table 1 - Seed germination, moisture content, total sugars, reducing sugars, non-reducing sugars, total phenols and oil content in the seeds at different stages of capsule maturity in J. curcas.

\begin{tabular}{lcccc}
\hline \multicolumn{1}{c}{ Parameter } & \multicolumn{3}{c}{ Capsule maturity } & CD $_{\mathbf{0 . 0 5}}$ \\
\cline { 2 - 4 } & Greenish yellow & Yellowish & Brownish black & \\
\hline Percent germination & $72.11 \pm 2.04$ & $85.78 \pm 1.39$ & $82.89 \pm 0.69$ & 0.85 \\
Moisture content (\%) & $41.82 \pm 0.31$ & $40.22 \pm 2.29$ & $36.17 \pm 2.07$ & 0.22 \\
Total sugar (mg/g) & $7.32 \pm 0.27$ & $10.33 \pm 0.57$ & $10.81 \pm 0.54$ & 0.18 \\
Reducing sugar (mg/g) & $2.23 \pm 0.15$ & $1.59 \pm 0.23$ & $1.49 \pm 0.13$ & 0.10 \\
Non-reducing sugar(mg/g) & $5.13 \pm 0.97$ & $8.68 \pm 1.77$ & $9.10 \pm 1.52$ & 0.20 \\
Starch (mg/gm) & $17.45 \pm 1.15$ & $16.35 \pm 0.45$ & $15.85 \pm 0.45$ & 0.08 \\
Total phenol (mg/g) & $6.36 \pm 0.16$ & $5.38 \pm 0.30$ & $5.37 \pm 0.64$ & 0.07 \\
Per cent oil content & $36.03 \pm 2.59$ & $46.70 \pm 1.67$ & $48.41 \pm 1.95$ & 0.24 \\
\hline
\end{tabular}

Values are means \pm SD 
Seeds collected at stage $\mathrm{C}_{3}$ of capsule maturity showed decreased germination percentage compared to those collected at stage $\mathrm{C}_{2}$. Similar trend in seed germination was observed under nursery conditions as well. Moisture content on percentage basis in the seeds declined as capsule maturity progressed from stages $\mathrm{C}_{1}$ to $\mathrm{C}_{3}$; the decline was more marked at stage $\mathrm{C}_{3}$. Total soluble sugars and non-reducing sugars increased whereas reducing sugars and starch content declined in the seeds with capsule maturity from stages $\mathrm{C}_{1}, \mathrm{C}_{2}$ and $\mathrm{C}_{3}$. The increase or decrease in these seed tissue constituents was less significant when capsule maturity progressed from stage $\mathrm{C}_{2}$ to
$\mathrm{C}_{3}$. Total phenol content in the seeds declined gradually with capsule maturity, the decline was non-significant from stage $\mathrm{C}_{2}$ to $\mathrm{C}_{3}$. Oil content in the kernels of seeds gradually increased with capsule maturity and the increase was much more significant from stage $C_{1}$ to stage $C_{2}$ of maturity than from stage $C_{2}$ to $C_{3}$. From the correlation studies, it was clear that the germination percentage showed a significant negative correlation with the moisture content, reducing sugars, starch and total phenols (Table 2). However, it was positively correlated with all other parameters, viz., total sugars, non-reducing sugars and oil content.

Table 2 - Correlation of various seed tissue constituents with seed germination percentage in Jatropha curcas.

\begin{tabular}{lcccccccc}
\hline Parameter & $\begin{array}{c}\text { Germination } \\
(\%)\end{array}$ & $\begin{array}{c}\text { Moisture } \\
(\%)\end{array}$ & $\begin{array}{c}\text { Oil } \\
\text { content }\end{array}$ & $\begin{array}{c}\text { Total } \\
\text { sugars }\end{array}$ & $\begin{array}{c}\text { Starch } \\
\text { content }\end{array}$ & $\begin{array}{c}\text { Total } \\
\text { phenols }\end{array}$ & $\begin{array}{c}\text { Reducing } \\
\text { sugars }\end{array}$ & $\begin{array}{c}\text { Non-reducing } \\
\text { sugars }\end{array}$ \\
\hline Germination $(\%)$ & 1.000 & $0.3272^{*}$ & $0.8256^{*}$ & $0.7676^{*}$ & $-0.7462^{*}$ & $-0.8219^{*}$ & $-0.7199^{*}$ & $0.7768^{*}$ \\
Moisture $(\%)$ & & 1.000 & $-0.5801^{*}$ & $-0.7564^{*}$ & $0.7926^{*}$ & $0.6264^{*}$ & $0.6416^{*}$ & $-0.7525^{*}$ \\
Oil content & & & 1.000 & $0.8913^{*}$ & $-0.8905^{*}$ & $-0.8416^{*}$ & $-0.8086^{*}$ & $0.8967^{*}$ \\
Total sugars & & & & 1.000 & $-0.9515^{*}$ & $-0.8978^{*}$ & $-0.8485^{*}$ & $0.9950^{*}$ \\
Starch content & & & & & 1.000 & $0.8801^{*}$ & $0.8554^{*}$ & $-0.9558^{*}$ \\
Total phenols & & & & & & 1.000 & $0.8449^{*}$ & $-0.9090^{*}$ \\
Reducing sugars & & & & & & 1.000 & $-0.8969^{*}$ \\
Non-reducing sugars & & & & & & & 1.000 \\
\hline
\end{tabular}

*Significant at $5 \%$ level of significance

Seeds generally accumulate their reserves in the endosperm, perisperm and embryo, more precisely in the cotyledons. In Jatropha seeds having kernels accounting for $63-68 \%$ of the total mass, the reserves accumulate in endosperm and very little in the embryo itself (Abou-Arab and Abu-Salem 2010; Lopes et al. 2013). Developing capsules and seeds act as strong sinks and a large quantity of soluble food reserves are translocated into them and converted into new storage forms such as starch, fats and proteins. Numerous other organic and inorganic constituents accumulate in them, whereas other constituents decrease as fruits/seed maturity progresses. Finally, capsules and seeds gradually reach maturation and cease to be active sinks and thereby translocation into these stops. The seeds harvested from $C_{1}$ maturity stage of capsules appeared physiologically immature as indicated by the high moisture content and lesser germination efficiency of the seeds. This meant that the nutrients were still flowing into the seeds from the parent tree. More significant increase in total soluble sugars, non-reducing sugars and oil content in the seeds as capsule maturity progressed from $\mathrm{C}_{1}$ to $\mathrm{C}_{2}$ stages than from $\mathrm{C}_{2}$ to $\mathrm{C}_{3}$ stage indicated physiological maturity of the seeds at $\mathrm{C}_{2}$ stage. The decrease in germination of the seeds harvested from the brownish-black capsules $\left(\mathrm{C}_{3}\right)$ could be due to the inter-conversion between non-reducing and reducing sugars. For germination, the reserve sugars have to be converted to soluble sugars. The decrease in germination could also be attributed to the impermeability of the testa caused by increasing lignification associated with the maturity. It seemed possible that as the fruits of Jatropha matured, starch was converted to sugars, resulting in an increase in total sugars. Starch content has been reported to gradually decline in Quercus nigra with the advancement of maturity, although there was no definite pattern of change in the contents of reducing and non-reducing sugars (Blanche et al.1990). Total phenols in the seeds also showed a gradual decrease with capsule maturity similar to that of starch. Similar declining trend of these constituents in the seeds with maturity has been reported by Bhupender et al. (2004) in Zizyphus mauritiana and Blanche et 
al. (1990) in Quercus nigra. The main metabolic substance of economic interest in the seeds of Jatropha are the lipids as a raw material for the bio-fuel industry. The oil content showed a definite increasing trend corresponding with capsule maturity with maximum oil content of $48.41 \%$ recorded in the seeds collected from $\mathrm{C}_{3}$ maturity stage. The oil content in the kernel seed of Jatropha ranges from 45-60\% (Parmanik 2003: Akintayo 2004). Gradual decline in reducing sugars in the seeds from $C_{1}$ to $C_{3}$ stages of capsule maturity with a concomitant increase in oil content may indicate conversion of former into later.

\section{CONCLUSIONS}

As the capsules/seeds mature, a number of measurable chemical changes take place. By correlating the relative amounts of selected biochemical constituents of capsule/seed maturity, a biochemical index of ripeness can be derived. Such an index is of use in large seed collections of plant species in a given area. Thus, in J. curcas yellowish and brownish-black were the maturity stages, yielding the seeds with maximum germination efficiency and oil-content, respectively. It could be suggested that yellowish capsules $\left(\mathrm{C}_{2}\right.$ stage), which were physiologically mature seed stage considering germination and oil content as criteria, could be harvested with more viable seeds rich in oil.

\section{ACKNOWLEDGMENTS}

The authors are grateful to Head, Department of Silviculture and Agroforestry, Dr Y.S. Parmar University of Horticulture \& Forestry, Nauni, Solan, Himachal Pradesh for providing necessary facilities for carrying out the work.

\section{REFERENCES}

Abou-Arab AA, Abu-Salem FM. Nutritional quality of Jatropha curcas seeds and effect of some physical and chemical treatments on their anti-nutritional factors. Afr J Food Sci. 2010; 4(3): 93-103.

Achten WMJ, Maes WH, Reubens B, Mathijs E, Singh VP, Verchot L, et al. Biomass production and allocation in Jatropha curcas L. seedlings under different levels of drought stress. Biom Bioener. 2010b; 34: 667-676.
Achten WMJ, Nielsen LR, Aerts R, Lengkeek AG, Kjær ED, Trabucco A, et al. Towards domestication of Jatropha curcas.2010a; Biofuels. 1(1): 91-107.

Akintayo ET. Characteristics and composition of Parkia biglobbossa and Jatropha curcas oils and cakes. Biores Technol. 2004; 92: 307-310.

Bhupender K, Singh C, Harinder K, Singh T, Gursharan K. Studies on physiological maturity and its effect on physical and biochemical characteristics in ber(Zizyphus mauritiana Lamk). Ind J of Ecol. 2004; 31(2): 143-146.

Blanche CA, Elam WW, Hodgar JD. Accelarated aging of Quercus nigra seeds: biochemical changes and applicability as a vigour test. Canad J For Res. 1990; 20: 1611-1615.

Bray HG, Thorpe WV. Analysis of phenolic compounds of interest in metabolism. In: D. Glick. Methods of Biochemical Analysis. Vol. I. New York: Interscience Publ. 1954.p.27-52.

Divakara BN, Upadhyaya HD, Wani SP, Gowda CLL. Biology and genetic improvement of Jatropha curcas L.: A review. Appl Energy.2010; 87: 732-742.

Dubois M, Gilles KA, Hamilton JK, Reders PA, Smith F. Colorimetric method for determination of sugars and related substances. Anal Chem. 1956; 28: 350-356

Fairless D. Biofuel: the little shrub that could - maybe. Nature. 2007; 449(7163): 652-655.

GEXSI. Global Market Study on Jatropha-Final Report. Global Exchange for Social Investment LLP, Berlin, Germany; 2008.

Gmunder S, Singh R, Pfister S, Adheloya A, Zah R. Environmental Impacts of Jatropha curcas Biodiesel in India. Journal of Biomedicine and Biotechnology 2012 (Article ID 623070, doi:10.1155/2012/623070)

King AJ, He W, Cuevas JA, Freudenberger M, Ramiaramanana D, Graham IA. Potential of Jatropha curcas as a source of renewable oil and animal feed. $J$ Exper Bot. 2009; 60: 2897-2905.

Lopes L de S, Gallao MI, Bertini CHC de M. Mobilisation of reserves during germination of Jatropha seeds. Rev Ciênc Agron. 2013; 44(2): 371378.

Miller GL. Use of dinitrosalicylic acid reagent for determination of reducing sugar. Anal Chem. 1959; 31: 420-428.

Mundra SL, Rao SS. Jatropha curcas- a promising short rotation forestry plant for dry and humid plains and Arawalli hills of Rajasthan. UHF-IUFRO International conference on world perspective on short rotation forestry for industrial and rural development. Sep. 7-13, 2003.p.46.

Namasivayam C, Sangeetha D, Gunasekaran R. Removal of anions, heavy metals, organic and dyes from water by adsorption into a new activated carbon from Jatropha husk, an agro-industrial solid waste. Process Saf Environ. 2007; 85: 181-184. 
Panse VG, Sukhatme PV. Statistical methods for agriculture workers. ICAR, New Delhi. 1978.

Pramanik K. Properties and use of Jatropha curcas oil and diesel fuel blends in compression ignition engine. Renew Energ. 2003; 28: 239-248.

Reddy JN, Ramesh A. Parametric studies for improving the performance of a Jatropha oil-fuelled compression ignition engine. Renew Energ. 2006; 31: 1994-2016.

Reubens B, Achten WMJ, Maes WH, Danjon F, Aerts $\mathrm{R}$, Poesen $\mathrm{J}$ et al. More than biofuel? Jatropha curcas root system symmetry and potential for soil erosion control. J Arid Environ. 2011; 75: 201-205.

Rodriguez-Acosta M, Vega-Flores K, De GanteCabrera VH. Distribucion del genero Jatropha L. (Euphorbiaceae) en el estado de Puebla, Mexico. Polibotanica. 2009; 28:37-48.
Silip JJ, Tambunan AH, Hambali H, Sutrisno, Surahman M. Lifecycle Duration and Maturity Heterogeneity of Jatropha curcas Linn. J Sust Dev. 2010; 3(2): 291-295.

Tewari JP, Dwivedi HD, Pathak M, Srivastava SK. Incidence of a mosaic disease in Jatropha curcas L. from eastern Uttar Pradesh. Curr Sci. 2007; 93: 10481049.

Tiwari A, Kumar A, Raheman H. Biodiesel production from jatropha oil (Jatropha curcas) with high free fatty acids: an optimized process. Biom Bioener. 2007; 31: 569-575.

Valdes-Rodriguez OA, Sanchez-Sanchez O, PerezVazquez A, Caplan J. The Mexican Non-toxic Jatropha curcas L., Food Resource or Biofuel. Ethnobotany Res Appl. 2013; 11:1-7. 